\title{
INVESTIGATIONS ON A BULL'S HEAD FROM PYRGOS/MAVRORAKI (LM) TO DESIGN THE BIODIVERSITY OF CYPRUS IN EARLY-MIDDLE BRONZE AGE.
}

\author{
A. Lentini, and M.R. Belgiorno
}

\author{
CNR Institute for Technologies Applied to Cultural Heritage - Via Salaria Km 29,500 P.O. Box \\ 10 - 00015 Monterotondo St., Rome, Italy, alessandro.lentini@,itabc.cnr.it
}

\begin{abstract}
KEY WORDS: Bronze Age, Palaeoenvironments, Sedimentology, Paleopalynology, Biodiversity, Hybridism
\end{abstract}

\begin{abstract}
:
The site of Pyrgos-Mavroraki near Limassol in Cyprus, destroyed by an earthquake in 1900-1850 B.C., is situated in an elevated position in the center of a vast settlement of the ancient and Middle Bronze Age before the Calcolitic period. The unchanged position of the structures and the finds, that remained unknown for 4000 years near the homonym village, offers a unique opportunity to carry out sedimentological, paleopalinolocical and archeobotanic investigations on totally uncontaminated materials. The results of the sedimentological and paleopalynology investigations and the characterization of other plants micro remains found in the samples from the bull's head SL (PY 09 D.10 B) make it possible to formulate some considerations on the vegetation in the ancient landscape.
\end{abstract}

\section{Introduction:}

Pyrgos-Mavrorachi is an archaeological site that has visual structures to enhance understanding. The ruined state of the site has acquired significance in its own right, and today the site forms part of a landscape that is publicly accepted as having special cultural significance. All the area is distinguishable by heritage resources, which should have the potential to become an interpretive and educational instrument for the public and a tourist attraction.

The Bronze Age settlement is in on elevated position, situated on the slope of a low hill (Mavroraki) in the middle of valley formed by a crossing of streams. In its proximity, there is the large harbour of Amathunte and three smaller sheltered anchorages.

The site was located in 1995, surveyed in 1996-97 and excavated during the years $1998-2009-2012$ by the Italian Archaeological Mission of CNR at Pyrgos/Mavroraki in Cyprus.

The excavations brought to light an important Middle Bronze Age industrial settlement $\left(2^{\text {nd }}\right.$ millennium BC) in an exceptionally state of in situ preservation material, overlying a previous occupation of the late $3^{\text {rd }}$ millennium $\mathrm{BC}$. Consequently, Pyrgos has significantly enriched our knowledge of the development of Limassol region and has provided more solid foundations for our understanding of Early-Middle Bronze Age Cypriot metallurgy.

The Pyrgos area was classified as protected, by a Department of Antiquities Decision in 2002 and some plots (for an extension of almost 2 hectares) have been expropriated for the excavation. Evidence of the first establishment of people in Early Bronze age has been found along the ridge of the side of the excavated area, on the medium slopes of the Mavroraki hill. They consist in architectural remains and assemblage of pottery that attest to the existence of earlier phases, belonging to dwellings destroyed by later buildings constructed on a sort of terrace North to the Pyrgos river.

The inclination of the hill helped the distribution of the buildings on different levels and their reuse and superimposition by later buildings.
The dimension and distribution of the Pyrgos/Mavrorachi settlement was calculated and mapped in 1999-2000. Recurrent surveys, carried on during the excavation seasons, revealed the settlement was distributed near the the western branch of the river Pyrgos, for a length of 700 metres, between the locations of "Kolla" and "Perivolia", including the small terrace of "Aulaki", on the southern side and the Mavrorachi hill 500 metres west to the old "koriò". The number of stone tools and fragments of pottery guided the estimation of the settlement length. The documentation recovered designs of a specific pattern of metallurgical settlement in which the guide element is given by the emerging presence of copper outcrops and watercourses, directly connected to the main activity of the inhabitants. The nearest mines localised in the surrounding area of the Pyrgos village create an axis that ran parallel to the coastline, an identifiable large way of copper with the alignment of the villages of Monagroulli, Monì, Pyrgos, Parekklisha and Aghios Thyconas. The recovery of galleries of ancient cultivation testifies the millenarian exploiting activity of the zone, turns to the achievement of the mixes sulphides outcrops. This it has been confirmed from the analyses of the slag of EMB age recovered at Pyrgos. Before the discovery of the Mavrorachi complex, the first small-scale copper production was estimated to have started in Cyprus after the second half of the $2^{\text {nd }}$ millennium BC.

However, the Pyrgos evidence points to an earlier date and demonstrate that centuries before that time, the Middle Bronze Age society was able to organise an industrial production of copper (Belgiorno, 2004, 2009). The site is important not only for its industrial identity but for the intact prehistoric levels, buried by the sudden collapse of the walls after the earthquake. This particular condition allows, through archeology, archaeometry, paleobotany, paleozoology and etnoarchaeology investigations to reconstruct the II millennium $\mathrm{BC}$ process of metallurgy, agriculture, medicine and textile production. A second building was discovered and brought to light in 2008 south of the industrial area.

This is a unique construction, consisting of two rooms arranged in a triangular area. 


\section{1 .Selection method: casual randomization}

The head (Fig. 1) is $28 \mathrm{~cm}$. long and $10 \mathrm{~cm}$ wide; the maximum height from the poll to the base of the cheek is $11 \mathrm{~cm}$. A piece of the horns was also recovered $(7 \mathrm{~cm}$. long, $3 \mathrm{~cm}$. wide, $4 \mathrm{~cm}$. thick).

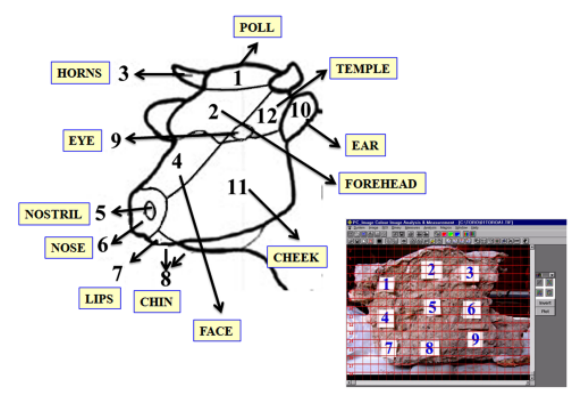

Figure 1, Anatomical areas of the bull's head to the side of the micro-areas grid for casual randomization.

Ten micro cores of material were selected with the randomization method, and a grid of 25 micro areas was set up, corresponding to all the recognizable parts of the bull's head. Simple random sampling is done by extracting a certain percentage of units from identified and numbered micro areas by a method that guarantees the randomness of the extractions. A classical way to obtain randomness is to pick out a number (as in lotteries) from a list (the sampling list) of all the numbered micro areas (Tab. 1). In our case, we used an appropriate computer program and checked the randomness of the sample against tables that generate random numbers (Spiegel Murray, 1961). A Microsoft Excel spreadsheet can be used for this purpose, inserting the function = RANDOM (), which gives a random decimal number between 0 and 1 . We used the formula $=$ INT(RANDOM ()$* 25+1$, which gives a random number between 1 and 25 .

\begin{tabular}{cc}
\hline D & ANATOMICAL AREA \\
\hline T25 & Cheek left \\
T12 & Temple right \\
T8 & Pool left \\
T3 & Base horn left \\
T15 & Neck right \\
T4 & Ear right \\
T16 & Forehead left \\
T6 & Face left \\
T11 & Nose right \\
\hline T1 & Pool right \\
\hline
\end{tabular}

Table 1. List of numbers extracted.

Simple randomizations, like other sampling methods, is valid for sampling in multiple disciplines, and it offers two advantages. First, it satisfies the requirements of good sampling: all the micro areas have the same probability of being chosen. Second, it makes it possible to assess the reliability of the results obtained.

\section{The sedimentological investigation}

The sediments were treated with $\mathrm{H}_{2} \mathrm{O}_{2}$ (hydrogen peroxide) at $36 \%$ to remove organic matter. Subsequently they were mixed with a solution of $\left(\mathrm{NaPO}_{3}\right) 6$ (sodium hexametaphosphate) and placed under stirring for 48 hours. Various density measurements obtained with calibrated reference hydrometers (Mériaux method) were carried out over 24 hours, in a sedimentation tank at a controlled temperature. To be able to determine how the natural landscape in the Pyrgos area changed over time, a preliminary sedimentological investigation was performed on the micro samples selected from the bull's head discovered in SL PY 09 D10B. The granulometry of the ten micro samples (Fig. 2) can be defined silty clayey with low percentages of sand. Particular interest is the digenetic process that affected the head of the bull after its initial deposition, the finer particles of clay and silt have replaced the original organic tissues with lithification dug around the complex, also incorporating different fragments of pottery in the SL investigated.

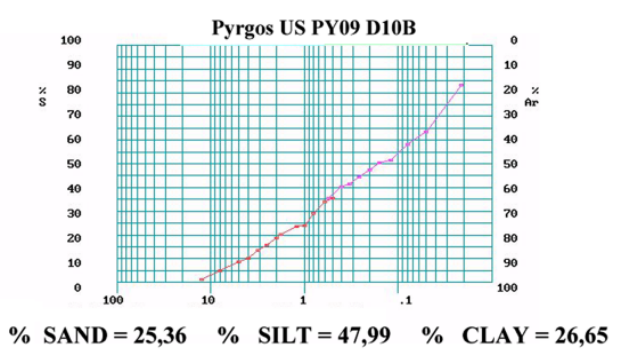

Figure 2, Sedimentological curve of SL PY 09 D10B.

The finest clay and slime particles replaced the original organic tissues, lithifying the whole excavated complex and incorporating pottery shards present in the SL. In this micro environment, the shallowness of the interment of the heterogeneous complex surely intensified the bacterial activity that broke down the original organic matter. The morphoscopic analysis of the granulometric fraction $>2 \mathrm{~mm}$ shows a series of windborne quartz crystals that confirm the site's exposed character (Lentini, 2009).

The diagrams of the granulometry and the presence of human elements show that the site was occupied continuously, due essentially to two main interlinking features one of the natural origin and the other of human origin that contributed to the build up of the deposit.

\section{Paleopalynological results}

This study was based on the results obtained from an initial screening of the texture of the sediments, the $\Delta \mathrm{pH}$ measurements and the quantity of organic matter. To protect the samples from external pollution, the paleopalynological extraction was performed with methods that prescribe the use of $\mathrm{HCl}$ and $\mathrm{HF}$ in a sterile environment. To calculate absolute pollen frequencies, the number of granules per gram of sediment a tablet of Lycopodium was added to each sample.

The average number of pollen granules counted per micro sample ranged from 984 to 1548 . The pollen spectra are based on the total number of granules counted (Walker, Pittelkow,1981). The findings are shown in table 2, which lists the identified species and their respective percentages, in their order of immigration, and also in two graphs (Figs. 3 and 4).

The first refers to the AP NAP ratio (arboreal and non arboreal plants) found by adding up pollen from trees and grassy plants, the. second shows the species most represented. Figure 3 shows the percentage palynological graph produced with Tilia and Tilia Graph software (Grimm, 2002). Further information about identification of 


\begin{tabular}{|c|c|c|c|c|c|c|c|c|c|c|}
\hline TAXA & T25 & T12 & T8 & T3 & T15 & T4 & T16 & T6 & T11 & T1 \\
\hline \multicolumn{11}{|c|}{ Irano-Turanic } \\
\hline Cedrus sp. & 3,66 & 3,63 & 3,67 & 3,57 & 3,34 & 3,2 & 2,96 & 3,18 & 3,67 & 4,24 \\
\hline Pinus sp. & 6,59 & 6,8 & 6,56 & 6,35 & 7,17 & 6,99 & 6,57 & 6,92 & 7,35 & 7,24 \\
\hline Juniperus sp. & 6,92 & 4,84 & 4,65 & 4,57 & 4,26 & 4,22 & 4,19 & 4,23 & 3,97 & 3,66 \\
\hline Cupressus sp. & 6,51 & 4,16 & 5,08 & 5 & 4,83 & 4,66 & 4,98 & 4,52 & 4,41 & 3,95 \\
\hline \multicolumn{11}{|c|}{ Riparian vegetation } \\
\hline Alnus sp. & 3,74 & 3,85 & 3,39 & 3,21 & 3,55 & 3,5 & 3,75 & 3,53 & 3,31 & 3 \\
\hline Ulmus sp. & 3,25 & 2,15 & 2,55 & 2,58 & 2,84 & 2,77 & 3,18 & 2,89 & 3,16 & 2,93 \\
\hline Popolus sp. & 3,09 & 3,85 & 3,46 & 3,57 & 3,43 & 3,24 & 3,75 & 3,48 & 3,49 & 3,64 \\
\hline Salix sp. & 1,24 & 1,89 & 1,97 & 2,5 & 2,2 & 2,11 & 2,09 & 2,19 & 2,2 & 2,34 \\
\hline Juncaceae & 1,20 & 1,10 & 1,33 & 1,06 & 1,18 & 1,20 & 1,16 & 1,18 & 1,07 & 1,04 \\
\hline Ferns & 0,81 & 0,91 & 1,06 & 1,14 & 1,28 & 1,46 & 1,44 & 1,69 & 1,62 & 1,46 \\
\hline Nymphaceae & 1,05 & 0,83 & 0,99 & 1,07 & 1,56 & 1,75 & 1,37 & 1,41 & 1,54 & 1,61 \\
\hline \multicolumn{11}{|c|}{ Mediterranean } \\
\hline Quercus sp. & 3,09 & 3,78 & 3,46 & 2,85 & 3,41 & 2 & 3,32 & 3,39 & 2,31 & 3,51 \\
\hline Prunus s.p. & 2,85 & 3,63 & 3,53 & 3,21 & 3,55 & 3,71 & 4,04 & 4,23 & 3,67 & 3,95 \\
\hline Olea sp. & 1,96 & 1,83 & 1,20 & 1,85 & 1,54 & 1,28 & 1,2 & 1,08 & 1 & 1,45 \\
\hline Pistacia sp. & 2,28 & 3,4 & 3,39 & 3,28 & 3,97 & 4,22 & 3,97 & 4,02 & 3,97 & 2,57 \\
\hline Laurus sp. & 4 & 4,46 & 3,03 & 4,07 & 3,83 & 3,86 & 3,61 & 3,81 & 3,75 & 3,58 \\
\hline Myrtus sp. & 3,39 & 2,71 & 4,58 & 4,35 & 3 & 4,44 & 3,2 & 3,08 & 3,89 & 3,66 \\
\hline \multicolumn{11}{|l|}{ Crops } \\
\hline Cerealia & 4,56 & 6,12 & 6,28 & 6,85 & 6,03 & 6,41 & 5,85 & 6,21 & 6,61 & 7,17 \\
\hline $\begin{array}{l}\text { Linum sp. } \\
\text { Anthropocore }\end{array}$ & 2,85 & 3,02 & 3,03 & 3,21 & 2,98 & 2,91 & 2,89 & 2,75 & 2,57 & 2,27 \\
\hline Graminaceae & 3,25 & 5,52 & 4,8 & 4,35 & 4,19 & 4,66 & 3,97 & 3,95 & & 4,02 \\
\hline Artemisia sp. & 3,4 & 3,25 & 2,82 & 3,21 & 2,48 & 2,26 & 2,74 & 2,82 & 2,79 & 2,63 \\
\hline $\begin{array}{l}\text { Urtica sp. } \\
\text { Autochthono }\end{array}$ & 3,58 & 1,89 & 2,12 & 2 & 2,13 & 2,04 & 2,02 & 2,12 & 1,76 & 1,83 \\
\hline Papaver sp. & 3,09 & 3,1 & 3,1 & 3,28 & 3,48 & 3,28 & 3,25 & 2,89 & 2,94 & 2,78 \\
\hline Lilium ssp. & 2,03 & 1,59 & 1,76 & 2 & 2,13 & 1,97 & 2,24 & 2,26 & 2,13 & 1,98 \\
\hline Hedysarum ssp. & 2,93 & 2,65 & 2,68 & 2,85 & 3,19 & 2,99 & 3,1 & 2,82 & 2,5 & 2,27 \\
\hline Tulipa ssp. & 1,71 & 1,74 & 1,76 & 1,71 & 2,06 & 2,18 & 2,02 & 2,19 & 2,2 & 2,05 \\
\hline Potentilla sp. & 1,62 & 1,44 & 1,55 & 1,78 & 1,99 & 2,26 & 1,52 & 1,76 & 2,06 & 2,19 \\
\hline Iris ssp. & 1,46 & 1,51 & 1,76 & 2 & 1,56 & 1,82 & 2,02 & 1,48 & 1,62 & 1,76 \\
\hline Gagea ssp. & 1,79 & 1,89 & 2,12 & 2,28 & 2,06 & 1,97 & 2,17 & 2,19 & 2,57 & 2,78 \\
\hline Narcissus ssp. & 1,22 & 1,36 & 1,27 & 1,42 & 1,35 & 1,46 & 1,52 & 1,41 & 1,76 & 1,83 \\
\hline Rosa ssp. & 2,52 & 2,87 & 3,1 & 2,71 & 1,28 & 1,38 & 1,44 & 1,55 & 1,69 & 1,76 \\
\hline Spores & 0,81 & 1,13 & 0,71 & 0,85 & 1,06 & 1,02 & 1,3 & 1,41 & 1,32 & 1,46 \\
\hline Indeterminate & 1,14 & 0,83 & 0,78 & 0,92 & 0,85 & 0,73 & 0,72 & 0,85 & 0,81 & 0,73 \\
\hline
\end{tabular}

Table 2. Summary table percentage of Taxa identified with the paleopalynological analysis.

several palynological zones. In the phases represented the micro samples that were examined, trees such as Cedrus, Pinus, Cupressus and Quercus are present in significant percentage. They are native to the Irano-Turanic region and are reported as growing wild in neighbouring areas. All species reported during the first paleopalynological investigations of SL PY 04H6 are found today in the spontaneous vegetation of Cyprus, on the Troodos massif. The analytic data seem to suggest the Mediterranean steppe forest with pollens from Juniperus, Pistacia, Olea, Laurus and Myrtus, thanks to the hot and humid climate. The woodland component includes Mediterranean evergreens such as the evergreen or Kermes oak (Quercus) and other oak species, olive trees (Olea sp.,), pistachio trees (Pistacia sp.) and plum trees (Prunus sp.), which were also identified in the paleopalynological study of the SL PY 04H6

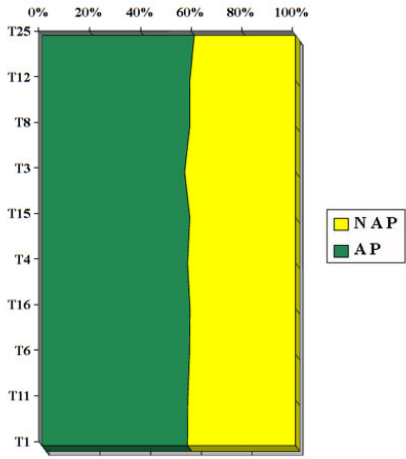

Figure 3, Cumulative AP NAP summary diagram. 
(Lentini, 2009b); as noted above, these trees remain from an older, Mediterranean type phase. In an earlier and more humid phase, this Mediterranean type plant alliance had probably managed to spread farther south than the area where it exists today. The third part of the graph shows the natural arboreal vegetation representative of a streamside environment: willows (Salix), poplars (Populus), alder (Alnus), elm (Ulmus) and grapewine (Vitis) in association with water loving plants such as rushes (Juncus), Ferns and water lilies (Nymphaceae), which testify to the strong influence of hydrological features on the island of Cyprus.

\subsection{Anthropisation indicators}

The evidence for these factors, plotted in the central parts of the palynological graph with a significant portion of spectra, due to the cultivation of grain and textiles plant (Greig, 1982), produces curves with indicative trends when, as in this case, they belong to anthropised palynological contexts (Lentini, 2009). The morphobiometric study of these pollen types was recently recast with the aid of an image analyser. Automatic counts and measurements of morphobiometric features (as proposed by S. T. Andersen) were made for Cerealia and the other Graminaceae. The presence of Cerealia is evidenced by four types of pollen. Pollen from plants belonging to the Hordeum group: Hordeum vulgare L. (cultivated barley), Triticum monococcum L. (einkorn wheat) and certain wild species.. Pollens from wheat and oats, the Triticum/Avena group, are present from the all microsamples and become a constant presence on the graph. The analytic procedures found no evidence of contamination. The state of preservation of these pollens is not such as to justify their attribution to a period different from that of the rest of the characterised species, and there appeared to be no phytogeographic reason to do so. As a result, they have been included as contemporary with the rest of the spectra, even if their trend can be thought a case of under representation that can be associated with the ancient forms of agriculture (Lentini, 2009). The palynological morphologies found in the micro samples seem to come from the moment of maximum expansion of the farmland vegetation, but the pollens from Genista, Artemisia, Chenopodium and Graminaceae already appear in this phase, all these are anthropochory that precede the formation of a garigue. This environmental context was essentially a combination of three elements the natural landscape, farmland and products selected by the frequenters of the site but a fourth element eventually came in it consisted of species such as Hedysarum, Tulipa, Potentilla, Iris, Crocus, Papaver, Lilium, Narcissus and Rosa sp.. The SL PY 09 D.10 B sector seems to have been an area where only selected floral species were brought in and preserved. The list of flowers resulting from the paleopalynological tests provides evidence of the native and endemic species present on the island of Cyprus (Lentini, 2099b).

\subsection{Geobotany and biodiversity in the Early Bronze Age}

The results of the sedimentological and palynological investigations and the characterization of other plants micro remains found in the samples from the bull's head (SL PY 09 D10 B) making it possible to formulate some considerations on the vegetation in the ancient landscape.

\subsection{Autochthonous herbaceous species}

Hedysarum sp.

This plant grows wild throughout the Mediterranean area, where it is thought it had its origins.
Hedysarum cyprium.

A member of the Fabaceae family, is the autochthonous species in Cyprus, today it grows wild on the vast plain of Mesaoria. This part of the island is historically one of the most affected by human activities and above all, one of the most irrigated and farmed. In the past documented deforestation, wildfires and fallowing caused soil erosion.

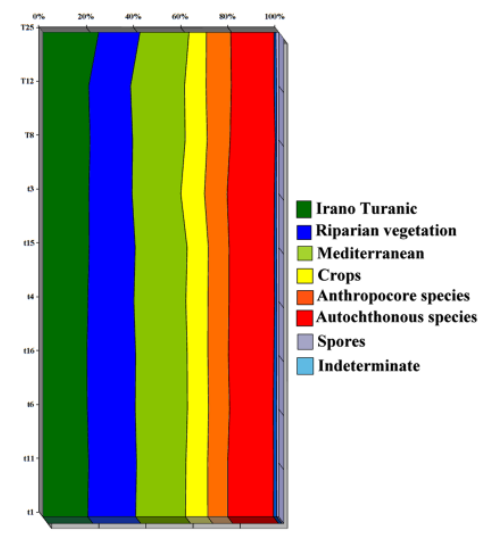

Figure 4, Palynological diagram divided in elements.

These developments led to the formation of garigue associated with anthropochory species, mainly Quercus coccifera, Olea europea L., Olea sylvestris and ChenopodiaceaeAmaranthaceae.

Crocus cyprium, Crocus veneris and Crocus hartmanianus.

The Crocus genus bulbous plants with linear leaves is extremely variable in its cytology (cell morphology and internal structure), since it has a large number of chromosomes (polyploidia). The chromosome numbers range from $2 n=6$ to $2 n=30$. This circumstance leads to a high degree of segregation among local species (groups of geographically isolated individuals can evolve quickly into more or less different forms), and consequently, to a very high difficulty in classifying them. These grassy perennials grow everywhere in Cyprus. Crocus cyprium appeared for the first time between the illustrations of the Codex Aniciae Julianae, also known as the Codex Vindobonensis, the Codex Byzantinus or the Vienna Dioscorides, the oldest and finest illustrated copy of the Greek physician Dioscorides's De materia medica.

Papaver sp.

The presence of Papaver is especially interesting. Poppies grow wild in the Mediterranean area, and are generally present on the edges of tilled fields. There are five autochthonous species in Cyprus, Papaver argemone ssp. meiklii [Kadereit Syn.: P. minus sensu Meikle], Papaver rhoeas ssp. cyprius, Papaver rhoeas var. oblongatum and Papaver orientale var. bracteatum. They are distributed over the area from the Troodos and Pentadactyl mountains to Stavrovouni, and have also been reported near the seaside in Paphos and Limassol.

Tulipa cypria.

This bulbous perennial is native to Cyprus, it grows at medium altitudes in the Troodos mountains.

Euphorbia veneris.

This perennial species contains a poisonous latex that is still used in the pharmaceutical industry. It grows wild in calcareous soils in the Troodos mountains and in the glades of the Paphos forest.

Rosa sp.

The rose genus includes around 150 species, many varieties and a huge number of hybrids. They grow wild about the medium altitudes of the Troodos mountains and can appear in the form of bushes, low trees and creepers. 


\section{DESIGN THE BIODIVERSITY OF CYPRUS IN EARLY-MIDDLE BRONZE AGE.}

Iris sp.

A bulbous perennial whose flowers can be white, violet or yellow. It blooms in the spring in the medium altitude glades of the Troodos mountains. It is used for medical purposes and in making perfume.

Potentilla reptans

A perennial species with woody rhyzome and solitary flowers, usually yellow. It grows wild in the territories of Prodromos, Trikoukia, Myrtou and Rizokarpaso, and blooms between May and June.

Lilium candidum (Fig.5).

This species has a scaly bulb and produces white flowers (solitary or grouped); it grows wild in all the island's micro environments.

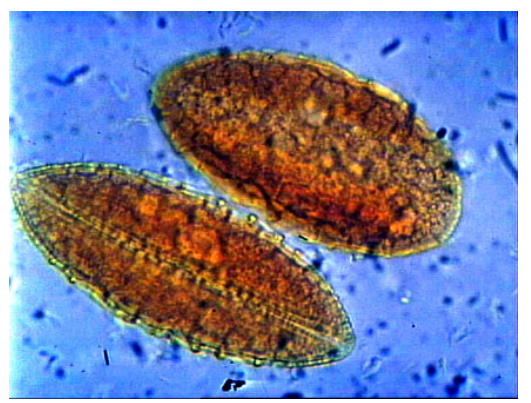

Figure 5, Pollen types of Lilium sp. (40 X).

Narcissus tazetta - A bulbous species that grows wild in the rocky soil of Ayia Napa and Karpassia. The flowers are unusual in that they bloom in bunches atop leafless stalks.

\section{Phytoliths}

The phytoliths like the pollen grains and sediments have a very useful function in the analysis, since they are always in significant quantities. It is also very well preserved in ancient sediments and have shapes and sizes that generally allow you to identify the genus or species that generated them. Analysis of these siliceous crystals, together with the paleopalynological investigation can provide additional information for the reconstruction ancient environment. For morphological descriptions has been used the Twiss P.C. nomenclature (Twiss, et alii, 1969). With the use of this classification is not always easy to determine the differences in morphological parameters. Generally, the morphological parameters are considered complementary to more specific studies on the plant epidermal tissues that have undergone a process of silicification. Moreover, in the observations and calculations of morphologies can be expected randomization of microsamples examined.

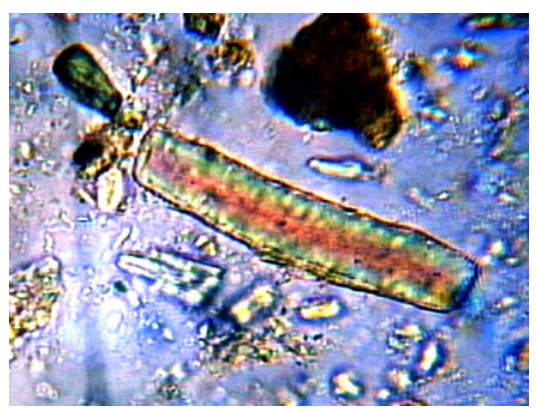

Figure 6, Quadrangular morphology (40 X)
The group is composed of phytoliths documented crop species such as Triticum sp. (Fig.6) and Hordeum sp.. From the characterization of phytoliths anthropochory species such as Bromus sp. can be observed, Carex sp. and Juncus sp. is among the species that makes up the riparian vegetations.

\section{Textile fibers}

The fibers and organic materials found were the subject of chemical and morphobiometric analyses to obtain a detailed definition of their origin and evolution. The features examined have been compared with fibers from the same species of different collections. The fiber and woven materials were treated with a solution of glycerin and $50 \%$ bi-distilled water.

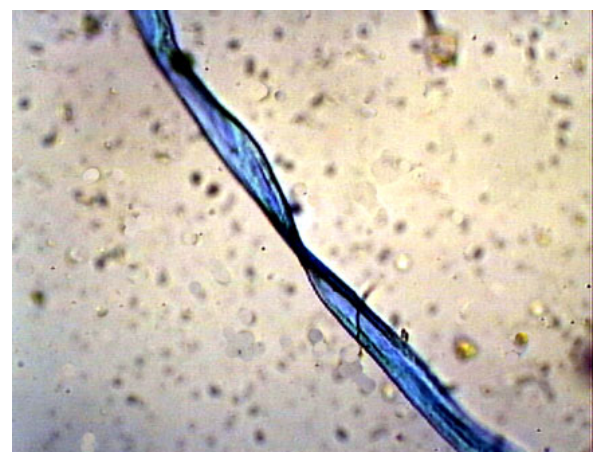

Figure 7, Mineralized fiber of cotton (10X).

The fibers and woven materials, all of which were particularly deteriorated, were consolidated with a $5 \%$ vinyl acryl nitrile emulsion. The morphobiometric study of the different fibers was done using an image analyzer. We initially examined 45 morphologies 20 of cotton (Gossypium sp. - Fig.7), the most relevant of the vegetable fibers with fibers of Linum sp. (10) and 15 filaments of wool.

\section{Spores}

Spores were found of fungi (Alternaria - Fig.8, Epicoccum, Stemphyllum, Drachslera, Fusarium and Didymella) typical of nitrophilous environments and often present in quiescent elevated structures (walls and artifacts of different nature).

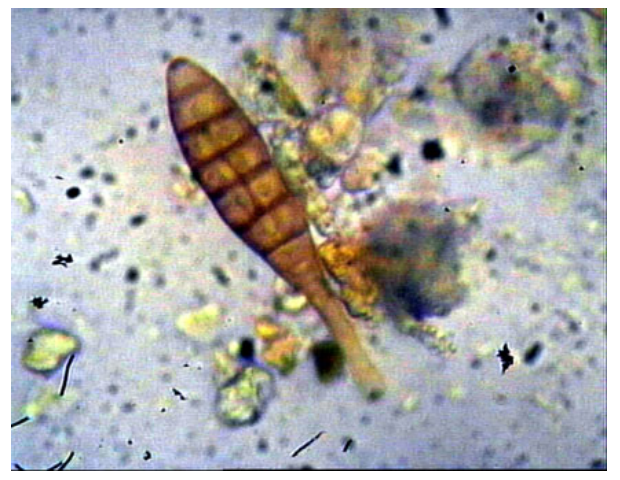

Figure 8, Spore of Alternaria ssp. (40X).

The outdoor spores had been deposited in the indoor sediments by climatic vectors such as wind and water, and by the comings and goings of humans. 


\section{Stomata and structures of the lower epidermis of leaves}

During the paleopalynological analysis of samples T3 (Fig. 9), T6, T8 and T16 were shown some structures and stomata epidermis of the underside of some leaves in SL PY 09 D10 B

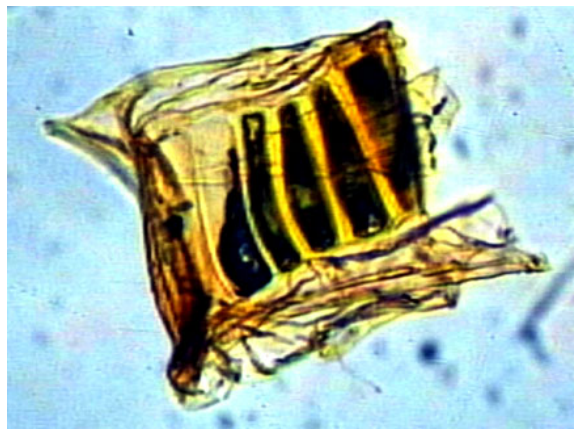

Figure 9, Stomata cells (40X).

The presence of these biological structures, may indirectly confirm the hypothesis of a particular area of the archaeological site of Pyrgos, where they were selected plant species. Furthermore, the position of the stomata open showed a cool damp climate.

\section{Hybridism and vegetation in Cyprus}

The presence of a significant number of autochthonous species in Cyprus in the Early Bronze Age poses a number of questions for both the paleopalynological and the archaeological investigations, the natural hybridization in an isolated and genetically segregated environment and on the possible intentional selections made by the island's sedentary population. The difficulty of interpreting evidence in this context was described during the analysis of sediments contained in a pottery vessel found in SL PY03 H5L6 (Lentini, 2009b) problems were caused by the presence of mono and sesquiterpene hydrocarbons and their non volatile derivatives in Citrus oil. The little documentation existing on the origin of this species located generically between the eastern Mediterranean and the subtropical east makes its classification very complex. Based on recent genetic applications, there exist only three species of Citrus; all the other members of the genus that used to be considered species or subspecies should actually be considered natural hybrids. The hybridism found in this context probably derives from cross-pollinations between different species. In general, botanists distinguish between different types of hybridization, depending on the systemic affinities between the crossbred species. Hybridization between varieties of the same species is fairly common. In many cases, it is a natural process caused by a whole series of accidental factors. Cross fertilization is usually a two way process, if the pollen succeeds in fertilizing the oosphere. Statistically hybridization produces individuals that are more vigorous than the two parent species and have better organoleptic and biochemical qualities, due to the heterosis effect. When the hybrid ripens and is ready to reproduce its characters begin to separate, according to the laws of heredity. The paleoenvironmental evidence found at Pyrgos in eight years of plant micro and macro vestiges investigation points out a context that included the presence of species whose morphology was halfway between wild species and species being produced by human selection. This aspect of the paleovegetation in Cyprus was showed over the time and by the way biometric measurements of paleoseeds of Triticum sp., Hordeum sp., Lens sp., Cicer sp. and Vitis ssp., all sifted out of material found in SUs G7L3, H5L6, J6L6, J6L5, J6L6, J5L8, J7L5 and F8L4. Cyprus's location at the southeastern boundary between the Mediterranean region and the Pontic region (the Irano-Turanic element) and the Near East (the Syriac and Nubo Sindic elements - Zohary, 1973) does not seem to have effectively influenced the most important endemic species, in fact they were probably preserved by the island's microclimates and particular edaphic conditions. The preliminary results obtained at Pyrgos suggest that the local climate was cool and moist, as it has been found in other southern Mediterranean sites dating from 1900-2000 B.C.. In those environmental conditions, with a cool and moist temperature, you can find today vegetation at medium and high altitudes, while, in 1900-2000 B.C, they were likely to grow at lower altitudes closer to the sea. Later on the most representative biocenoses gradually moved to higher altitudes, where the environmental conditions were still cool and moist. This happened partly because of the Mediterranean basin climate changing and (Barbero, Quezel, 1979) partly because of the increasingly intense human activities.

\section{Conclusions}

The set of results obtained from the micro samples selected from the bull's head discovered in SL PY 09D.10B presents essentially two phases. The first one occurred during a hot and moist climate period characterized by components of the Mediterranean and streamside biome (already reported during the study of the SL PY04 H6 stratigraphic section). The second phase was characterized by the significant presence, in the palinologic record, of grassy and bushy floral species native to the island of Cyprus and associated with the presence of phytoliths, textile fibres and epithelial plant structures that point in this SL to an activity of selection of very particular plant species. The presence of various phytoliths of Triticum sp., Hordeum sp., Bromus sp. and Juncaceae, and the high percentages of floral species, seem to be associated with intentional dynamics, because of the presence of all the elements needed to fabricate floral compositions, decorations, ornaments and garlands.

\section{References}

Andersen, S.Th., 1978-9. Identification of wild grass cereal pollen, Geological Survey of Denmark 79, 69-92.

Barbero, M., and Quezel, P., 1979. Contribution á l'étude des groupements forestiers de Chypre, Documents Phytosociologiques, 4, 30 - 45.

Belgiorno, M.R., 2004. Pyrgos Mavrorachi Advanced Technology in Bronze Age Cyprus, CNR Bureau President's, Nicosia.

Belgiorno, M.R., 2009. Cipro all'inizio dell'Età del Bronzo, Realtà Sconosciute della Comunità Industriale di PyrgosMavrorachi, Gangemi Editore, Roma.

Greig, I., 1982. The interpretation of pollen spectra from urban archaeological depots, Council for British Archaeology, London, 43, 47-65.

Grimm, E., 2002. Tilia and Tilia Graph, Illinois State Museum Newsletter, Springfield, Illinois.

Lentini, A., 2009. Indagini archeobotaniche e fisico chimiche, In: Belgiorno M.R., Cipro all'inizio dell'Età del Bronzo, Realtà Sconosciute della Comunità Industriale di Pyrgos Mavrorachi, Gangemi Editore, Roma, 129 - 187.

Lentini, A., 2009b. New archaeobotanical data on the cultivation of Vitis ssp. at Pyrgos-Mavrorachi, Notes of Kinyras, Since $4^{\text {th }}$ Millennium B.C. and Evidence from Erimi, 
Cyprus Wine Museum and Department of Antiquities Museum, Nicosia, $56-73$.

Spiegel Murray, R., 1961. Statistics, McGraw Hill Book Company, New York.

Twiss, P.C., Suess, E. and Smith, R.M., 1969. Morphological of Grass Phytoliths, Soil Science of America, 33, 109-115.

Walker, D. and Pittelkow, Y., 1981. Some applications of the independent treatment of taxa in pollen analysis, Journal of Biogeography, 8, 37-51.
Zohary, M., 1973. Geobotanical Foundation of the Middle East, vol. 2, Fischer Verlag, Stuttgart, Swets and Zeitlinger, Amsterdam. 
